\title{
Vitis vinifera VvNPR1.1 is the functional ortholog of AtNPRI and its overexpression in grapevine triggers constitutive activation of $P R$ genes and enhanced resistance to powdery mildew
}

\author{
Gaëlle Le Henanff • Sibylle Farine $\cdot$ Flore Kieffer-Mazet $\cdot$ Anne-Sophie Miclot • \\ Thierry Heitz $\cdot$ Pere Mestre $\cdot$ Christophe Bertsch $\cdot$ Julie Chong
}

Received: 16 February 2011/Accepted: 31 March 2011/Published online: 20 April 2011

(C) Springer-Verlag 2011

\begin{abstract}
Studying grapevine (Vitis vinifera) innate defense mechanisms is a prerequisite to the development of new protection strategies, based on the stimulation of plant signaling pathways to trigger pathogen resistance. Two transcriptional coactivators (VvNPR1.1 and VvNPR1.2) with similarity to Arabidopsis thaliana NPR1 (NonExpressor of $P R$ genes 1), a well-characterized and key signaling element of the salicylic acid (SA) pathway, were recently isolated in Vitis vinifera. In this study, functional characterization of VvNPR1.1 and VvNPR1.2, including complementation of the Arabidopsis nprl mutant, revealed that $V v N P R 1.1$ is a functional ortholog of AtNPRl, whereas $V v N P R 1.2$ likely has a different function. Ectopic
\end{abstract}

G. Le Henanff · S. Farine - F. Kieffer-Mazet · C. Bertsch · J. Chong $(\bowtie)$

Université de Haute Alsace, Laboratoire Vigne, Biotechnologies et Environnement (EA3991), 33 rue de Herrlisheim,

68000 Colmar, France

e-mail: julie.chong@uha.fr

A.-S. Miclot · P. Mestre

INRA, UMR1131 Santé de la Vigne et Qualité du Vin, 68000 Colmar, France

A.-S. Miclot · P. Mestre

Université de Strasbourg, UMR 1131 Santé de la Vigne et

Qualité du Vin, 68000 Colmar, France

Present Address:

A.-S. Miclot

UMR Génétique et Horticulture (GenHort), IFR149 QUASAV,

Centre INRA Angers-Nantes, BP 60057, 49071 Beaucouzé,

France

T. Heitz

IBMP du CNRS (UPR2357), Département Réseaux

Métaboliques chez les Végétaux, 12 rue du général Zimmer,

67000 Strasbourg, France overexpression of $V v N P R 1.1$ in the Arabidopsis nprl-2 mutant restored plant growth at a high SA concentration, Pathogenesis Related 1 (PRI) gene expression after treatment with SA or bacterial inoculation, and resistance to virulent Pseudomonas syringae pv. maculicola bacteria. Moreover, stable overexpression of VvNPR1.1-GFP in $V$. vinifera resulted in constitutive nuclear localization of the fusion protein and enhanced $P R$ gene expression in uninfected plants. Furthermore, grapevine plants overexpressing VvNPR1.1-GFP exhibited an enhanced resistance to powdery mildew infection. This work highlights the importance of the conserved SA/NPR1 signaling pathway for resistance to biotrophic pathogens in $V$. vinifera.

Keywords Vitis vinifera $\cdot$ Arabidopsis thaliana $\cdot$ Defense response signaling $\cdot$ Salicylic acid - Disease resistance

$\begin{array}{ll}\text { Abbreviations } \\ \text { BTH } & \text { Benzothiadiazole } \\ \text { EDS1 } & \text { Enhanced disease susceptibility } \\ \text { ET } & \text { Ethylene } \\ \text { INA } & \text { 2.6-dichloroisonicotinic acid } \\ \text { JA } & \text { Jasmonic acid } \\ \text { MeJA } & \text { Methyljasmonate } \\ \text { NPR1 } & \text { Non-expressor of } P R \text { genes } 1 \\ \text { PR } & \text { Pathogenesis related } \\ \text { SA } & \text { Salicylic acid } \\ \text { SAR } & \text { Systemic acquired resistance }\end{array}$

\section{Introduction}

Grapes are a major fruit crop but grapevine is generally susceptible to attack by diverse pathogens including 
oomycetes, fungi, bacteria or viruses, and its culture requires the intensive use of phytochemicals. It has been estimated that the European Union employs 68,000 tons/ year of fungicides to control grape diseases, while grapevine culture occupies $3.3 \%$ of the arable soils in the EU (Muthmann 2007). To find alternative strategies to the use of pesticides, such as the application of elicitors of natural resistance in grapevine, it is necessary to have a sufficient knowledge of the signaling networks controlling the onset of defense responses in Vitis vinifera.

Plant responses to biotic stress involve intricate signaling networks that activate a set of appropriate defense responses specified by the type of inducing pathogen. In the model plant Arabidopsis thaliana, the hormones salicylic acid (SA), jasmonic acid (JA) and ethylene (ET) are key mediators of plant resistance to different types of pathogens. SA is involved in local resistance to biotrophs and in the onset of systemic acquired resistance (SAR), a broad spectrum and long lasting resistance that develops in noninoculated tissues following a primary pathogen infection (Thomma et al. 2001; Pieterse et al. 2009). Resistance to necrotrophs as well as induced systemic resistance, which is triggered by root-colonizing nonpathogenic rhizobacteria, are controlled by JA and ET (Glazebrook 2005; Pieterse et al. 2009). In Arabidopsis, SA regulates the expression of genes encoding a subset of pathogenesis-related (PR) proteins, i.e. $P R 1, P R 2$ and $P R 5$, whereas the JA-ET pathway controls the expression of a different set of defense markers such as PDF1.2 and $P R 3$. These PR proteins have been defined as $\beta-1,3$ glucanase (PR2), thaumatin-like protein (PR5), defensin (PDF1.2) and basic chitinase (PR3) (Thomma et al. 1998).

Although the signaling pathways involved in resistance to various pathogens are much less described in grapevine than in Arabidopsis, several studies have indicated a potential role of JA, ET, and SA in disease resistance in this species. Grape leaves pretreated with methyl jasmonate (MeJA) or ethephon, an ET-releasing compound, exhibited an enhanced tolerance to powdery mildew, correlated with increased expression of PR proteins (Belhadj et al. 2006, 2008). Treatment of grape leaves or cultured cells with MeJA also promotes the synthesis of stilbenes, which are major phytoalexins in this species (Tassoni et al. 2005; Belhadj et al. 2006). More recently, an analysis of the defense responses to downy mildew in a susceptible (Vitis vinifera cv. Pinot Noir) and a resistant (V. riparia cv. Gloire de Montpellier) grapevine species revealed that resistance in $V$. riparia involves the modulation of transcripts of enzymes involved in JA biosynthesis as well as higher levels of both JA and MeJA in the leaves (Polesani et al. 2010).
Besides JA and ET, SA is also likely to be an important mediator of grapevine defense responses. A comparison between powdery mildew-resistant $V$. aestivalis $\mathrm{cv}$. Norton and susceptible $V$. vinifera cv. Cabernet Sauvignon showed that the resistant Norton variety has constitutively high contents of SA. High SA levels are correlated with constitutively elevated expression of genes involved in defense responses such as regulatory genes and genes encoding PR proteins or secondary metabolism enzymes (Fung et al. 2008). Treatment of grapevine with benzothiadiazole (BTH), a SA analog, enhanced resveratrol and anthocyanin contents of berries as well as their resistance to Botrytis cinerea, the causal agent of gray mold (Iriti et al. 2004). As shown in Arabidopsis, SA and JA-ET likely control the expression of different defense markers in grapevine (Chong et al. 2008).

NPR1 (Non-expressor of Pathogenesis Related 1, (Cao et al. 1994)), also called NIM1 (Ryals et al. 1997) or SAI1 (Shah et al. 1997), is a key signaling element mediating plant resistance to biotrophs and SAR in Arabidopsis. NPR1 was originally isolated in a screen for Arabidopsis mutants that fail to express the $P R 2$ gene following SA treatment (Cao et al. 1994). The NPRI gene controls the onset of SAR because nprl mutants pretreated with SA or an avirulent pathogen and subsequently inoculated with a virulent pathogen (e.g. Pseudomonas syringae or Hyaloperonospora parasitica) did not show restriction of pathogen growth in contrast to wild type Col0 harboring a functional NPRl gene (Cao et al. 1994, 1997). The NPRI gene is also important for local basal resistance: the virulent pathogen Pseudomonas syringae pv. maculicola grows to a greater extent in $\mathrm{nprl}$ mutants than in wild type plants (Cao et al. 1994; Glazebrook et al. 1996). AtNPRl encodes a protein containing a BTB/POZ domain and an ankyrin repeat domain, which are known to mediate protein-protein interactions (Cao et al. 1997; Ryals et al. 1997). Both domains are also found in the transcriptional regulator $\mathrm{I} \kappa \mathrm{B}$, an important mediator of the immune response in animals (Ryals et al. 1997). In addition to NPRl, the Arabidopsis thaliana genome contains five NPRI-related genes called AtNPR2 to AtNPR6 (Liu et al. 2005). Whereas AtNPR1 to AtNPR4 have been implicated in signaling of defense responses, AtNPR5 and AtNPR6 form a distinct group involved in the regulation of developmental patterning of leaves and flowers (Hepworth et al. 2005; Liu et al. 2005).

Further studies have revealed that NPR1 activity is regulated by cellular redox changes triggered by high SA accumulation during SAR. Under non-induced conditions, NPR1 is present as an oligomer formed through disulfide bonds and is sequestered in the cytoplasm (Mou et al. 2003). Upon SAR induction, the disulfide bonds are 
reduced, and NPR1 is converted to a monomeric form. Monomeric NPR1 is translocated to the nucleus, where it interacts with transcription factors from the TGA family to regulate the expression of defense genes (Kinkema et al. 2000; Mou et al. 2003).

AtNPR1 overexpression in Arabidopsis triggers enhanced resistance to the biotrophic pathogens $H$. parasitica and P. syringae pv. tomato (Cao et al. 1998). Higher resistance is correlated with faster and stronger expression of $P R$ genes after pathogen inoculation, suggesting that AtNPR1 overexpression triggers a "priming" state (Cao et al. 1998). Similarly, AtNPRI-overexpressing crop plants including rice, tomato, wheat, carrot, cotton and apple developed an enhanced resistance to fungal and bacterial pathogens (Chern et al. 2001; Fitzgerald et al. 2004; Lin et al. 2004; Makandar et al. 2006; Malnoy et al. 2007; Quilis et al. 2008; Wally et al. 2009; Parkhi et al. 2010).

The identification of mutants affected in signaling elements involved in disease resistance and the positional cloning of the mutated genes are impractical and time consuming in woody perennial plants such as grapevine. As an alternative strategy, we undertook a candidate gene approach and focused on grapevine genes that are putative homologs of AtNPR1. Two genes, VvNPR1.1 and $V v N P R 1.2$, encoding proteins with sequence similarity to AtNPR1 are present in the $V$. vinifera genome (Le Henanff et al. 2009; Bergeault et al. 2010). Phylogenetic analyses demonstrated that the VvNPR1.1 protein is more closely related to AtNPR1 than VvNPR1.2, which groups with AtNPR3 and AtNPR4, two putative negative regulators of defense responses (Bergeault et al. 2010). We also have previously shown that transient overexpression of VvNPR1.1 in Nicotiana benthamiana and grapevine triggers enhanced expression of acidic PR proteins (Le Henanff et al. 2009).

In order to better understand the regulation of defense responses in grapevine, we addressed the question of whether the defense mechanisms are controlled by a pathway similar to the SA/NPR1-dependent pathway in Arabidopsis. To determine whether both VvNPRl.1 and $V v N P R 1.2$ fulfill the same function as AtNPR1, the two genes were stably overexpressed in the Arabidopsis $n p r l$ mutant. Phenotypic analyses revealed that VvNPR1.1 overexpression complements the $n p r 1$ mutation. VvNPRI.1 is therefore a functional ortholog of AtNPRl, whereas $V v N P R 1.2$ is likely to have a different function. VvNPRI.1 fused to GFP was further overexpressed in $V$. vinifera $\mathrm{cv}$. Chardonnay, where it triggers constitutive high expression of several $P R$ genes. VvNPRI.1 overexpressing plants also show enhanced resistance to powdery mildew infection. Overall, these data highlight an important role for VvNPR1.1 in grapevine defense against biotrophic pathogens.

\section{Materials and methods}

\section{Biological material}

Arabidopsis thaliana ecotype Col0 plants were grown under controlled conditions in a growth chamber under a $12 / 12 \mathrm{~h}$ photoperiod and a $20 / 16^{\circ} \mathrm{C}$ day/night temperature regime. Seeds of the $n p r l-2$ mutant were a gift from Dr J. Glazebrook (University of Minnesota, St Paul, USA).

Vitis vinifera $\mathrm{cv}$. Chardonnay 96 was obtained from ENTAV (Etablissement National Technique pour l'Amélioration de la Viticulture, Le Grau du Roi, France). This clone was propagated on Murashige and Skoog (MS) medium supplemented with $20 \mathrm{~g} / 1$ sucrose and $0.7 \%$ bactoagar in a growth chamber at $25^{\circ} \mathrm{C}$, under a $16 / 8 \mathrm{~h}$ photoperiod. Four-week-old in vitro plantlets of Vitis vinifera cv. Chardonnay were transferred to potting soil (Fertiligène, NFU 44-571) inside a closed translucide propagator under saturating humidity for 7 days. Plantlet acclimatization was realized by gradually raising the propagator's lid. Plants were grown in potting soil for 4 weeks $\left(22^{\circ} \mathrm{C}, 16 / 8 \mathrm{~h}\right.$ photoperiod, $70 \%$ humidity) before use for treatments or pathogen inoculation.

\section{Generation of transgenic Arabidopsis plants}

Full-length AtNPR1, VvNPR1.1 and VvNPR1.2 cDNAs were cloned between the CaMV $35 \mathrm{~S}$ promoter and the $35 \mathrm{~S}$ terminator sequences into the pBINplus vector as described in Le Henanff et al. (2009). All binary vector constructs were mobilized into the GV 3101 strain of Agrobacterium tumefaciens and used to transform Arabidopsis thaliana Col-0 or npr 1-2 mutant by the floral dip method (Bechtold and Pelletier 1998). For pathogen resistance experiments, homozygous T3 plants were used.

\section{Transformation of $V$. vinifera $\mathrm{cv}$. Chardonnay} with Agrobacterium tumefaciens and regeneration of transformed plants

Anther-derived embryogenic calli from Vitis vinifera cv. Chardonnay 96 were obtained as described by Mauro et al. (1986). Embryogenic calli developed 2 months after the dissection of anthers and were subcultured every 3 weeks on MPM1 medium (Perrin et al. 2001). The cultures were maintained at $25^{\circ} \mathrm{C}$ under a $16 / 8 \mathrm{~h}$ photoperiod.

Grapevine transformation was performed by a somatic embryogenesis-based method with kanamycin selection. Embryogenic calli ( 3 weeks after subculture) were transferred on MPM1 medium supplemented with active charcoal ( $2.5 \mathrm{~g} / \mathrm{l})$ just before transformation with Agrobacterium.

AtNPR1, VvNPR1.1 and VvNPR1.2 coding sequences were cloned by Gateway (Invitrogen) recombination 
reactions into the pK7FWG2 vector (Karimi et al. 2002), upstream of eGFP as described in Le Henanff et al. (2009). The constructs were mobilized into the $\mathrm{C} 58 \mathrm{C} 1$ strain of Agrobacterium tumefaciens. Overnight-grown Agrobacterium cultures in YEB medium at $28^{\circ} \mathrm{C}(\mathrm{OD}=0.6)$ were centrifuged $(3000 \mathrm{~g}, 5 \mathrm{~min})$ and washed three times with the same volume of MS medium supplemented with sucrose $(20 \mathrm{~g} / \mathrm{l})$ and acetosyringone $(100 \mu \mathrm{M})$. Once resuspended in MS medium with acetosyringone, the Agrobacterium suspension was agitated for $2 \mathrm{~h}$ at $28^{\circ} \mathrm{C}$ and $20 \mu \mathrm{l}$ were deposited on embryogenic calli. After $48 \mathrm{~h}$ of co-cultivation in the dark at $25^{\circ} \mathrm{C}$, calli were transferred to MPM1 medium supplemented with active charcoal $(2.5 \mathrm{~g} / \mathrm{l})$ and cefotaxime $(500 \mathrm{mg} / \mathrm{l})$ to remove contaminating Agrobacterium. After 3 weeks, calli were subcultured on MPM1 medium without charcoal and supplemented with cefotaxime $(500 \mathrm{mg} / \mathrm{l})$ and kanamycin $(100 \mathrm{mg} / \mathrm{l})$ to select transformed cells. Calli were then subcultured every 3 weeks on fresh MPM1 medium containing kanamycin $(100 \mathrm{mg} / \mathrm{l})$ and cefotaxime. After several subcultures, the calli that were able to grow on $100 \mathrm{mg} / \mathrm{l} \mathrm{kanamycin}$ were transferred to MPM1 medium containing $200 \mathrm{mg} / \mathrm{l}$ kanamycin. The presence of the transgene was PCR-checked on genomic DNA from kanamycin-resistant calli, with one primer designed in the $V v N P R 1.1$ sequence and one primer designed in the eGFP sequence (Table 1). GFP fluorescence observations allowed further identification of transformed calli. Kanamycin-resistant calli were subcultured on MPM1 medium supplemented with charcoal $(2.5 \mathrm{~g} / \mathrm{l})$ and without antibiotics to produce somatic embryos. Somatic embryos at the torpedo stage were transferred to a conversion medium (MS medium supplemented with $0.1 \mathrm{mg} / \mathrm{l}$ benzylaminopurine). The plantlets regenerated from germinated embryos were transferred to MS medium without hormones and were further propagated to cuttings on MS medium containing kanamycin $(5 \mathrm{mg} / \mathrm{l})$.

Treatment of plants with chemicals and pathogens

For Arabidopsis inoculation we used Pseudomonas syringae pv. maculicola ES4326 kindly provided by Drs J. Dewdney and S. Gopalan (Massachusets General Hospital, Boston, USA) and cultured at $28^{\circ} \mathrm{C}$ in King's B medium (bactopeptone $10 \mathrm{~g} / 1, \mathrm{KH}_{2} \mathrm{PO}_{4} 3 \mathrm{~g} / \mathrm{l}$, glycerol $20 \mathrm{~g} / \mathrm{l}$ ) supplemented with streptomycin $(100 \mu \mathrm{g} / \mathrm{ml})$. Infection of Arabidopsis with $P$. syringae was performed on 7-weekold soil-grown plants. For SA treatment, plants were sprayed with potassium salicylate $(0.5 \mathrm{mM}, \mathrm{pH} 6.5)$. $P$. syringae pv. maculicola ES4326 was grown overnight in $10 \mathrm{ml}$ of King's B medium supplemented with streptomycin. Cultures were washed with $10 \mathrm{mM} \mathrm{MgCl}{ }_{2}$ and leaves were infiltrated on the abaxial surface with a

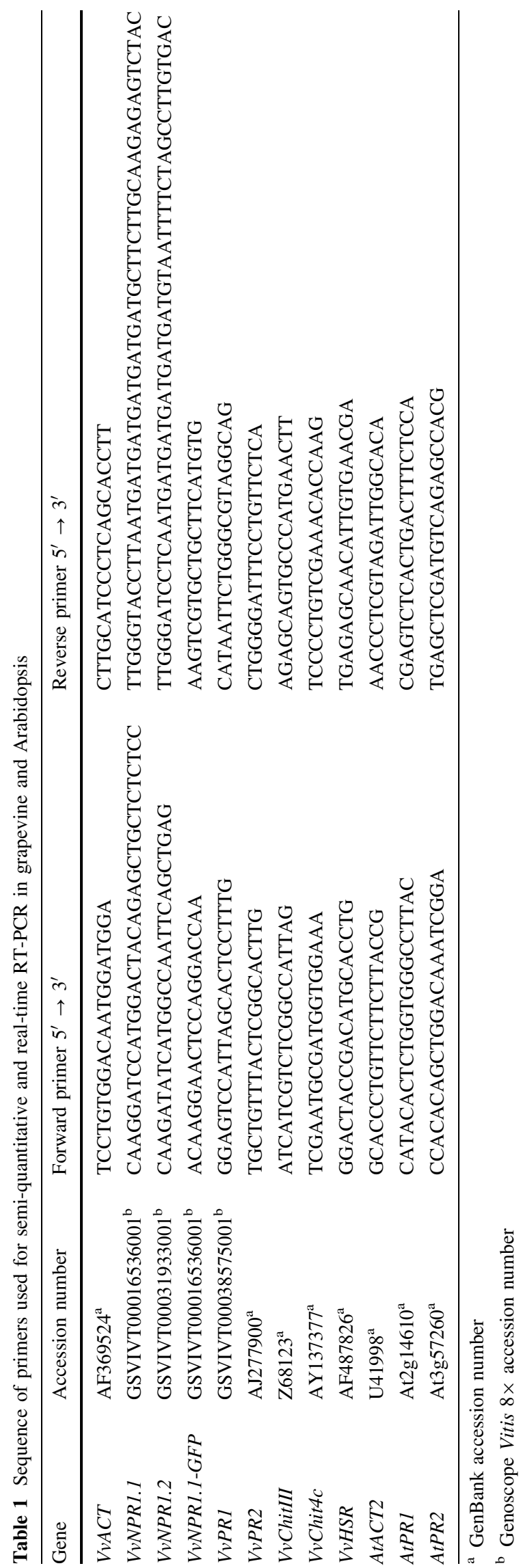


needleless $1 \mathrm{ml}$ syringe. Multiplication of $P$. syringae $\mathrm{pv}$. maculicola in leaves was determined as described in Katagiri et al. (2002).

For infection of $V$. vinifera with Erysiphe necator, we used acclimatized plantlets, 4 weeks after transfer to potting soil. Four independent plantlets were tested for each genotype. E. necator strain (biotype B) was isolated from a Merlot Noir leaf sample collected in the Château Latour Pauillac vineyard in 2004 and maintained on leaves of $V$. vinifera $\mathrm{cv}$. Muscat Ottonel. Detached young growing leaves (2-3 per plant) were decontaminated with $5 \% \mathrm{NaOCl}$, rinsed with sterile water, and dried. Detached leaves were deposited lower side down on sterile agar plates $(15 \mathrm{~g} / \mathrm{l})$ with petiole in the agar medium and the plates placed at the bottom of a settling tower. Conidia of $E$. necator were blown in at the top from sporulating leaves ( 20 conidia per $\mathrm{cm}^{2}$ of leaf). Inoculated leaves were incubated for 11 days at $25^{\circ} \mathrm{C}$ under a $16 \mathrm{~h}$ photoperiod $\left(50 \mu \mathrm{E} / \mathrm{m}^{2} / \mathrm{s}\right)$. Eleven days after inoculation, each leaf was immersed and agitated in $10 \mathrm{ml}$ isoton ${ }^{\circledR}$ (Beckman, Roissy, France). The number of conidia was determined in $1 \mathrm{ml}$ isoton, using a Beckman Coulter Counter $^{\circledR}$. The number of conidia was determined for 10 leaves from 4 independent plants for each genotype.

Gene expression analysis by semi-quantitative and realtime quantitative RT-PCR

RNA extraction and DNase I treatment were performed as described in Chong et al. (2008). Reverse transcription was performed on $0.5 \mu \mathrm{g}$ RNA using the SuperScript II Reverse Transcriptase (Invitrogen, Cergy Pontoise, France) and oligodT priming as recommended by the supplier. Semiquantitative PCR was performed as described in Le Henanff et al. (2009).

For real-time PCR, reactions were carried out on the iCycler system (Bio-Rad, Marnes-la-Coquette, France). $\mathrm{PCR}$ reactions were carried out in triplicates in a reaction buffer containing $1 \times \mathrm{iQ} \mathrm{SYBR}{ }^{\circledR}$ Green Supermix, $0.2 \mathrm{mM}$ of forward and reverse primers and $10 \mathrm{ng}$ of reverse transcribed RNA in a final volume of $25 \mu \mathrm{l}$. Thermal cycling conditions were: $2 \mathrm{~min}$ at $95^{\circ} \mathrm{C}$ followed by 40 cycles of $15 \mathrm{~s}$ at $94^{\circ} \mathrm{C}, 30 \mathrm{~s}$ at $60^{\circ} \mathrm{C}$ and $30 \mathrm{~s}$ at $72^{\circ} \mathrm{C}$. The calibration curve for each gene was obtained by performing real-time PCR with serial dilutions of the cloned cDNA fragment (from $10^{2}$ to $10^{8}$ cDNA copy number). The specificity of the individual PCR amplification was checked using a heat dissociation curve from 55 to $95^{\circ} \mathrm{C}$ following the final cycle of the PCR. The results obtained for each gene of interest were normalized to the expression of a reference gene (AtACT2, VvACT1) and fold induction compared to appropriate controls (see legend of figures) was calculated as described by Pfaffl (2001). Mean values and standard deviations were obtained from 3 technical and
2 biological replicates. Primers used for real-time quantitative PCR are listed in Table 1.

Subcellular localization of VvNPR1.1-GFP protein

$V v N P R 1.1$ in pK7FWG2 vector (Le Henanff et al. 2009) was transformed with $A$. tumefaciens into $V$. vinifera $\mathrm{cv}$. Chardonnay 96 calli as described above. Leaf sectors from transformed grapevine plantlets were observed. Images were acquired with a LSM510 confocal microscope (Carl Zeiss, software version AIM 4.2), using a $63 \times, 1.2$ NA water immersion objective lens at $23^{\circ} \mathrm{C}$. Fluorescence of GFP fusion proteins was observed after excitation with a $488 \mathrm{~nm}$ laser line, using a 505-550 nm band-pass emission filter.

\section{Statistical analysis}

For gene expression analysis by qRT-PCR, mean values and standard deviations were obtained from 3 technical and 2 biological replicates. For Psm resistance assays in Arabidopsis, statistically significant differences in bacterial growth between genotypes were revealed by using a Mann and Whitney bilateral test $(P<0.05)$. For powdery mildew resistance tests in grapevine, mean values and standard deviations were obtained with 10 leaves from 4 independent plants for each genotype. Similar results were obtained in three independent experiments.

\section{Results}

$V v N P R 1.1$ but not $V v N P R 1.2$ overexpression restores growth at a high SA concentration and SA-dependent expression of defense markers in the Arabidopsis npr1-2 mutant

To investigate whether the $V v N P R$ genes have functions similar to Arabidopsis NPR1, the $V v N P R 1.1$ and $V v N P R 1.2$ coding sequences were placed under the control of the CaMV $35 \mathrm{~S}$ promoter and transformed into the Arabidopsis nprl-2 mutant. Homozygous nprl-2 T3 lines overexpressing $V v N P R 1.1$ or $V v N P R 1.2$ were selected (Fig. 1a).

Arabidopsis nprl mutants are characterized by a reduced tolerance to high SA concentrations and show arrested growth as well as cotyledon bleaching when grown on $500 \mu \mathrm{M}$ SA (Cao et al. 1997). Seeds of the T3 nprl-2 mutant overexpressing $V v N P R 1.1$ or $V v N P R 1.2$ were sown on synthetic MS medium containing $400 \mu \mathrm{M}$ SA. The growth of plantlets was visualized 2 weeks later. As expected (Fig. 1b), nprl-2 mutants transformed with the empty vector (pBin) were unable to develop on $400 \mu \mathrm{M}$ SA, whereas wild type Columbia (WT Col0) plantlets displayed normal growth and green leaves. Most nprl-2 
Fig. $1 V v N P R 1.1$ expression in the Arabidopsis nprl-2 mutant restores plant growth and $P R$ gene expression after SA treatment. Analysis of transgene expression (a), growth at a high SA concentration (b) and $P R$ gene expression levels (c) in Arabidopsis WT Col0 and nprl-2 mutant transformed with empty vector (pBin-3 and pBin7); 35S:VvNPR1.1 (VN1.1-6 and VN1.1-8); or 35S:VvNPR1.2 (VN1.2-2 and VN1.2-12). a Total RNA was extracted from T3 homozygous lines. Full-length cDNA from each transgene was specifically amplified after reverse transcription with primers listed in Table 1. AtACT2 was used as internal control. b Seeds of T3 homozygous lines were sown on MS medium containing $400 \mu \mathrm{M}$ SA and photographs were taken 15 days later. c Seeds of T3 homozygous lines were sown on MS medium containing $100 \mu \mathrm{M}$ SA or MS medium without SA. Two weeks later, plantlets were harvested and analyzed for $P R 1$ and $P R 2$ gene expression levels by quantitative RTPCR. Transcript levels of $P R 1$ and $P R 2$ were normalized to actin transcript levels. The fold induction indicates normalized expression levels in MS + SA-grown plantlets compared to normalized expression levels observed in MS-grown plantlets. Mean values and standard deviations were obtained from 3 technical and 2 biological replicates. Note the different scales for $P R 1$ and $P R 2$ expression

plantlets expressing $V v N P R 1.1$ developed green leaves on medium with a high SA concentration, while most npr 1-2 seedlings expressing $V v N P R 1.2$ were bleached and unable to grow on $400 \mu \mathrm{M}$ SA (Fig. 1b).

The nprl mutants have also been characterized by their inability to express specific defense markers such as $P R I$ and PR2, following treatment with SA or its analogs (Cao et al. 1994). nprl-2 plantlets transformed with the empty vector (pBin), 35S:VvNPR1.1 or 35S:VvNPR1.2 were grown on MS medium or MS medium supplemented with $100 \mu \mathrm{M}$ SA. PRI and PR2 expression levels were studied by quantitative RT-PCR in 2 week-old plantlets (Fig. 1c). For each gene, the fold induction indicates normalized expression levels in $\mathrm{MS}+\mathrm{SA}$-grown plantlets compared to normalized expression levels in MS-grown plantlets. WT Col0 plantlets displayed a strong increase in $P R 1$ and $P R 2$ expression levels in the presence of SA. As expected, the expression of these defense markers was dramatically reduced in nprl-2 mutants transformed with the empty vector. Overexpression of $V v N P R s$ in the nprl-2 mutant did not modify the basal expression of the $P R$ genes in the absence of SA treatment (data not shown). In response to $\mathrm{SA}$, expression of $V v N P R 1.1$ in the nprl-2 background restored stimulation of both $P R 1$ and $P R 2$ expression levels. However, $V v N P R 1.2$ expression did not restore SAdependent $P R$ gene expression in the nprl-2 background: indeed the levels of $P R 1$ and $P R 2$ expression were even lower than in the empty vector lines (Fig. 1c).

Overexpression of $V v N P R 1.1$ improves basal resistance and SA-induced resistance to Pseudomonas syringae pv. maculicola in the Arabidopsis nprl-2 mutant

To get insight into the role of VvNPRs in basal resistance, we measured the resistance of nprl-2 mutants expressing

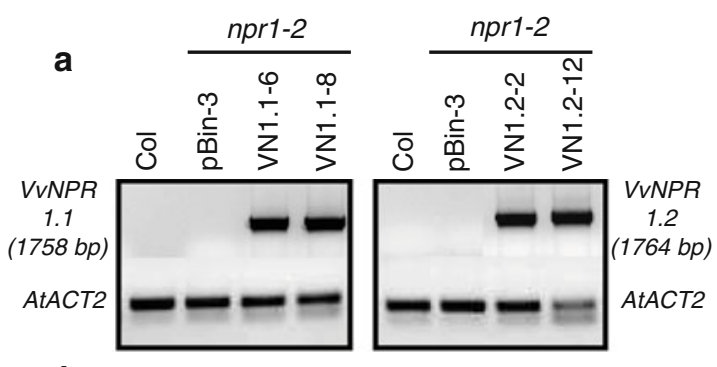

b
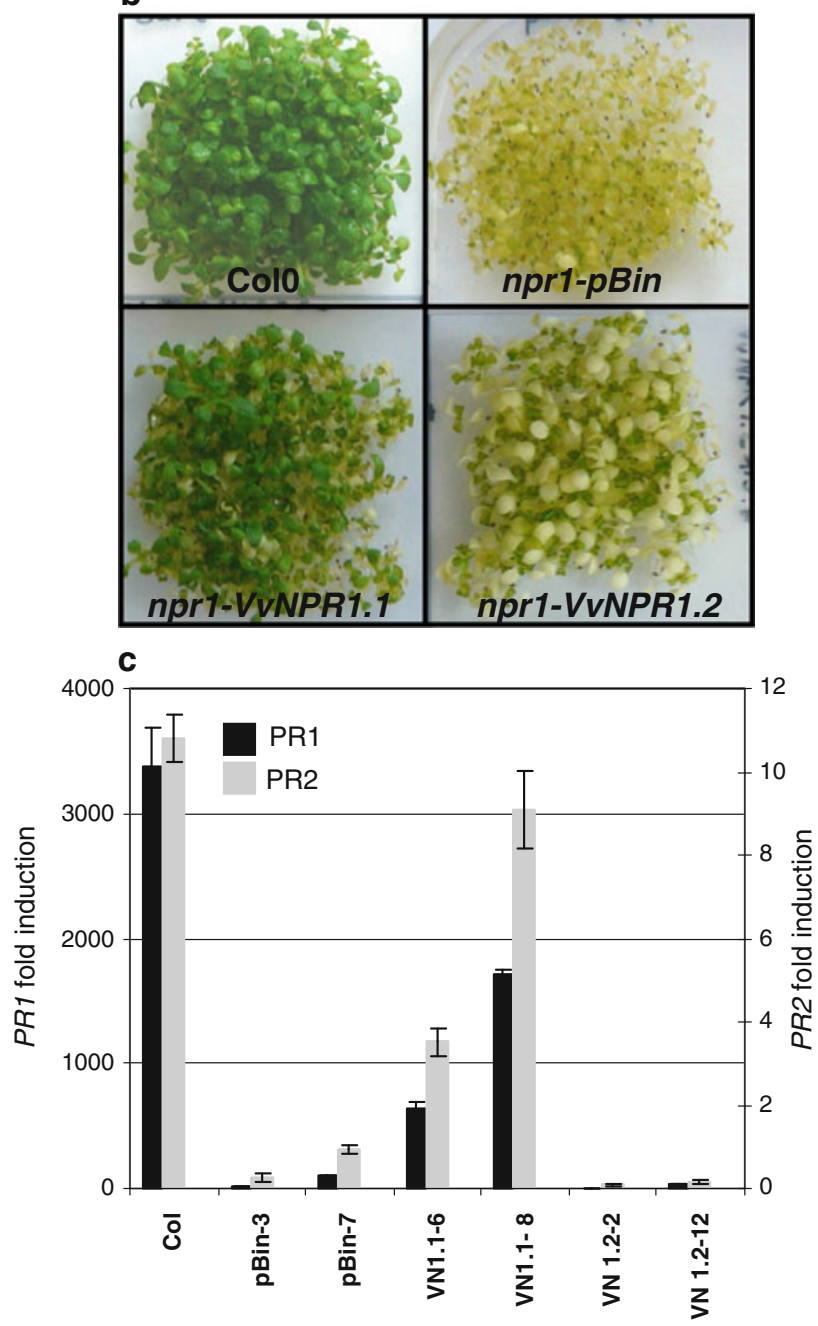

VvNPR1.1 or VvNPR1.2 to local bacterial infection with virulent Pseudomonas syringae pv. maculicola (Psm ES4326).

WT Col0 and nprl-2 mutants expressing VvNPRI.1 or $V v N P R 1.2$ were inoculated with Psm ES4326 and bacterial growth was measured $24 \mathrm{~h}$ and $72 \mathrm{~h}$ following inoculation. As shown in Fig. 2a, bacterial growth was approximately 10-fold higher in nprl-2 mutants transformed with the empty vector (pBin) than in WT Col0. Interestingly, expression of $V v N P R 1.1$ in the nprl-2 background reduced bacterial growth to levels observed in Col0. There was a 12-17-fold reduction in the number of colony forming 

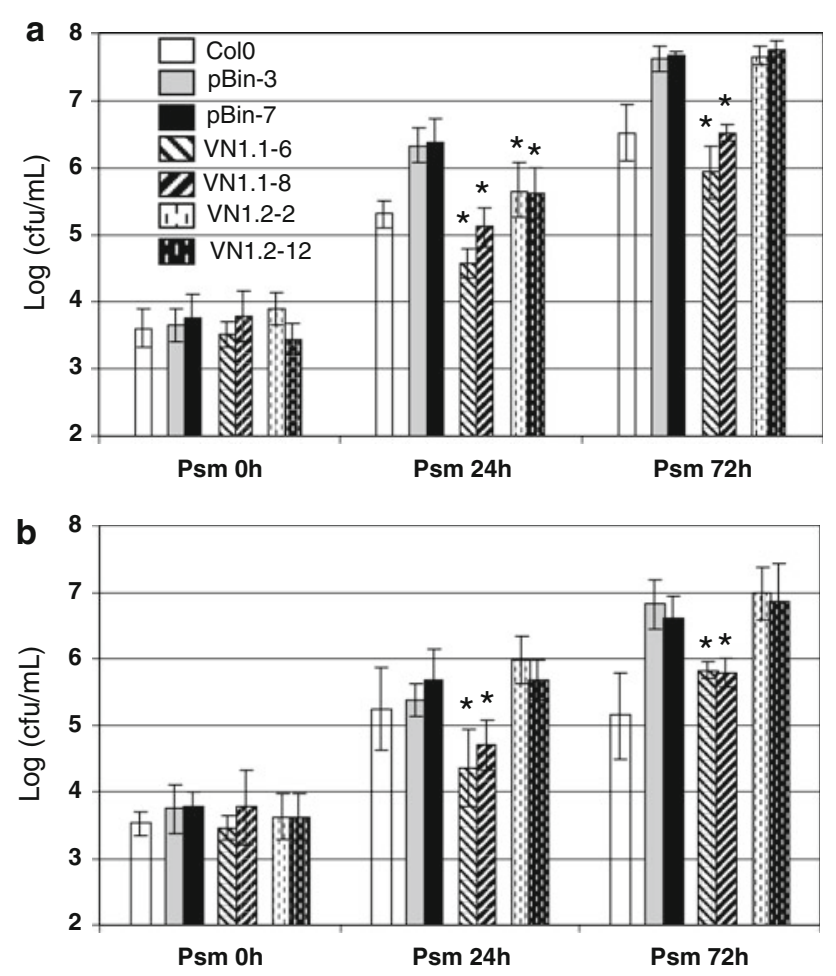

Fig. 2 Resistance of the Arabidopsis nprl-2 mutants overexpressing VvNPR1.1 or VvNPR1.2 to Pseudomonas syringae infection. 8-weekold Arabidopsis plants were syringe-inoculated with $P$. syringae pv. maculicola (Psm, $\left.2.5 \times 10^{5} \mathrm{cfu} / \mathrm{ml}\right)$. Two independent T3 lines were analyzed for $n p r 1-2$ transformed with the empty vector (pBin-3 and pBin-7), 35S:VvNPR1.1 (VN1.1-6 and VN1.1-8) and 35S:VvNPR1.2 (VN1.2-2 and VN1.2-12). Samples were taken from 6 independent plants for each genotype at 24 and $72 \mathrm{~h}$ post-inoculation. Mean values and standard deviations were obtained from 6 independent plants. The experiment was repeated twice with similar results. Asterisks indicate the plant genotypes where Psm growth is significantly lower than in the pBin controls. Statistically significant differences in Psm growth between genotypes were revealed by using a Mann and Whitney bilateral test $(P<0.05)$. a Analysis of basal resistance to Psm. b Plants were pretreated with $0.5 \mathrm{mM} \mathrm{SA} 72 \mathrm{~h}$ before inoculation with Psm

units (cfu) in the nprl-2 lines transformed with VvNPRl.1 compared to the lines transformed with the empty vector at 24 and $72 \mathrm{~h}$ following inoculation (Fig. 2a). The nprl-2 lines transformed with VvNPR1.2 showed a lower but significant reduction of bacterial growth $24 \mathrm{~h}$ after inoculation (7.5-fold reduction compared to the pBin lines). However, bacterial growth after $72 \mathrm{~h}$ in VvNPR1.2 lines was similar to that observed in $n p r l-2$ transformed with the empty vector.

To determine the impact of VvNPR1 on SA-induced resistance, a phenomenon that frequently determines the ability to deploy SAR, another group of plants was pretreated with SA 72 h before inoculation with Psm ES4326, and the resistance was measured at 24 and $72 \mathrm{~h}$ postinoculation (Fig. 2b). Bacterial growth at $72 \mathrm{~h}$ was about 10-fold lower in SA-pretreated plants compared to untreated plants (compare the bars at $72 \mathrm{~h}$ post-inoculation in Fig. 2a, b), reflecting the induction of resistance by SA. The bacterial titers were higher in the nprl-2 empty vector lines, especially at $72 \mathrm{~h}$ post-inoculation. The expression of VvNPR1.1 triggered a reduction of bacterial growth in the nprl-2 mutants, both at $24 \mathrm{~h}$ (8-12-fold reduction compared to the pBin lines) and at $72 \mathrm{~h}$ (8-9-fold reduction compared to the pBin lines) post-inoculation. In contrast, the expression of VvNPR1.2 in the nprl-2 background had no effect on Psm growth which was in the same range as in the empty vector lines for both time points (Fig. 2b).

Taken together, these results show that VvNPRI.1 expression can restore both basal and SA-induced resistance to virulent Psm ES4326 in the nprl-2 mutant.

Enhanced resistance triggered by VvNPR1.1 expression in the Arabidopsis nprl-2 mutant is associated with higher expression of SA-dependent defense genes after Psm infection

To investigate whether $V v N P R 1.1$ could complement the inability of the $n p r l-2$ mutant to mediate the expression of SA-dependent defense genes after pathogen infection, we monitored the expression of $P R 1$ and $P R 2$ by quantitative RT-PCR $48 \mathrm{~h}$ after inoculation with Psm ES4326.

The expression of the typical SA marker $P R l$ was highly induced in WT Col0 inoculated with Psm ES4326 (Fig. 3). As expected, the expression of $P R l$ was greatly reduced in nprl-2 mutants transformed with the empty vector. The expression of $V v N P R I .1$ restored induction of $P R I$ expression after Psm infection in the nprl-2 mutant to levels even higher than in Col0 (Fig. 3). The expression of $V v N P R 1.2$ did not enhance PRl expression in the nprl-2 background compared to the empty vector (Fig. 3). In contrast to $P R 1$, high levels of $P R 2$ expression were induced by Psm ES4326 infection both in Col0 and in all nprl-2 lines (Fig. 3). However, PR2 expression was 2-3fold higher in nprl-2 lines transformed with VvNPR1.1 compared to mutants transformed with the empty vector.

In conclusion, the enhanced Psm resistance observed in $n p r 1-2$ expressing VvNPRI.1 is associated with the highly induced expression of SA-dependent defense markers, especially $P R 1$.

\section{Overexpression of $V v N P R 1.1-G F P$ in Vitis vinifera plants}

The results obtained with Arabidopsis complementation show that $V v N P R 1.1$ is likely to be the grapevine functional ortholog of AtNPRI. To get further information about its function in a homologous system, the VvNPRI.1 coding sequence was fused to GFP and placed under the 


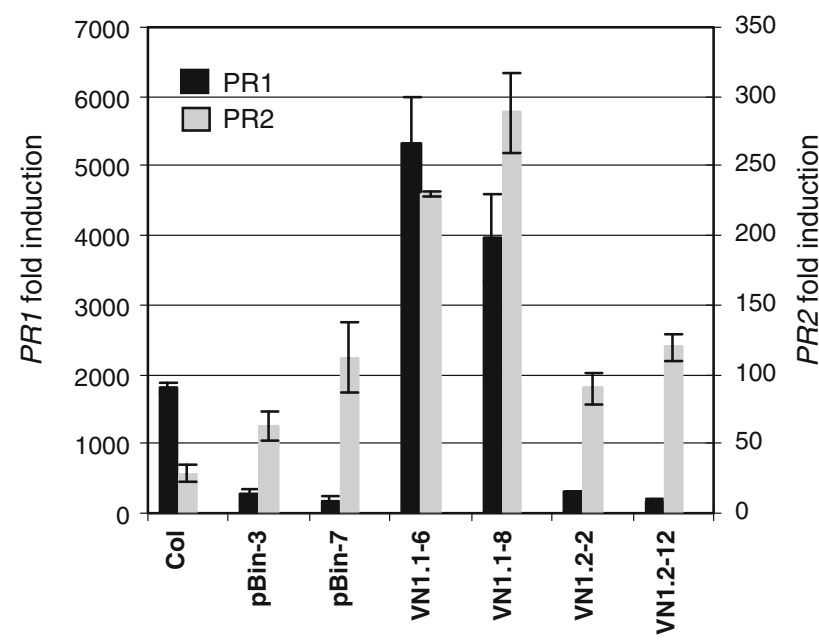

Fig. $3 P R 1$ and $P R 2$ expression levels in the Arabidopsis nprl-2 mutants overexpressing VvNPR1.1 or VvNPR1.2 after Pseudomonas syringae infection. Eight-week-old Arabidopsis plants were inoculated with $P$. syringae pv. maculicola $\left(\mathrm{Psm}, 2.5 \times 10^{5} \mathrm{cfu} / \mathrm{ml}\right.$ ) or $\mathrm{MgCl}_{2}$ alone. Two independent T3 lines were analyzed for $P R$ gene expression by quantitative RT-PCR $48 \mathrm{~h}$ after Psm inoculation. Transcript levels of $P R 1$ and $P R 2$ were normalized to actin transcript levels. The fold induction indicates normalized expression levels in Psm-inoculated plants compared to normalized expression levels observed in $\mathrm{MgCl}_{2}$-inoculated plants. Mean values and standard deviations were obtained from 3 technical and 2 biological replicates

control of the constitutive CaMV $35 \mathrm{~S}$ promoter. This construct was used to transform $V$. vinifera $\mathrm{cv}$. Chardonnay embryogenic calli with Agrobacterium tumefaciens. A GFP fusion was chosen to facilitate selection of fluorescent transformed cells from embryogenic calli. We have previously shown that VvNPR1.1-GFP is functional in triggering $P R I$ expression in $N$. benthamiana (Le Henanff et al. 2009). We finally obtained 5 independent transformants (T3, T4, T6, T7, T8) overexpressing VvNPR1.1-GFP that were propagated by microcuttings (Fig. 4a). Eightweek-old cuttings were subsequently transferred to soil and cultivated in a growth chamber. A significant rate of death during acclimatization was observed for plantlets overexpressing VvNPR1.1 compared to plantlets transformed with the empty vector (data not shown). Once acclimatized, the growth of VvNPR1.1 and empty vector plantlets was similar, but a loss of apical dominance was observed for all VvNPR1.1 transformants. As a result, the transformants appeared bushy compared to the empty vector controls (Fig. 4b).

GFP fluorescence was observed by confocal microscopy in both transformed calli in vitro and in young leaves of plantlets 5 weeks after their transfer to soil. Grapevine cells expressing GFP alone showed a weak fluorescence in the cytoplasm (data not shown). VvNPR1.1-GFP was
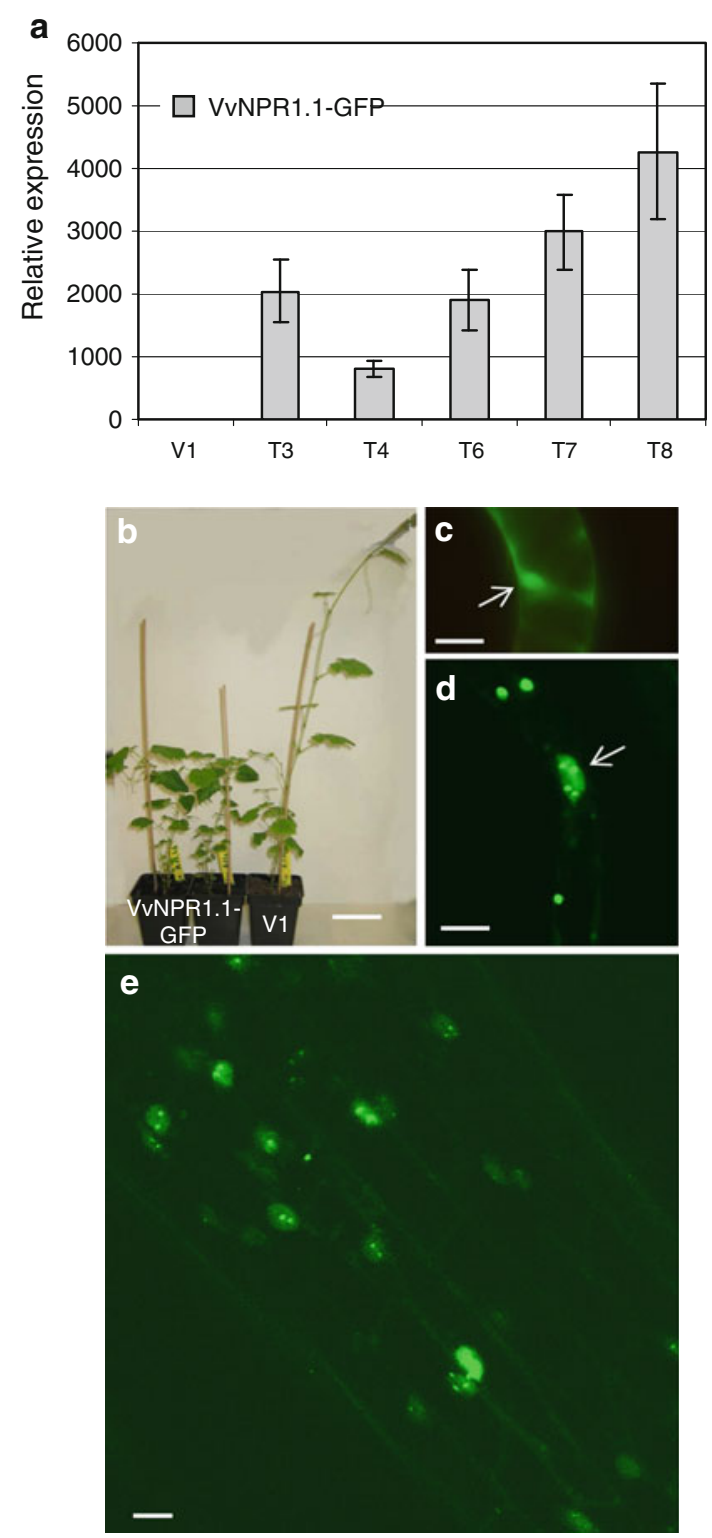

Fig. 4 Overexpression of $V v N P R 1.1-G F P$ in grapevine. a Total RNA was extracted from five independent in vitro-grown transformants (T3, T4, T6, T7 and T8). Expression of the VvNPR1.1-GFP transgene was studied by quantitative RT-PCR in in vitro Chardonnay plantlets transformed with the empty vector (V1) and in plantlets transformed with VvNPR1.1-GFP. Transcript levels of VvNPR1.1-GFP transgene were normalized to actin transcript levels. The relative expression indicates normalized expression levels in transformed plants compared to normalized expression levels observed in V1 plants. Mean values and standard deviations were obtained from 3 technical and 2 biological replicates. b Phenotype of VvNPR1.1-GFP overexpressing grapevine T4. Bar $=8 \mathrm{~cm}$. V1 = Chardonnay plant transformed with the empty vector. $\mathbf{c}, \mathbf{d}, \mathbf{e}$ Subcellular localization of VvNPR1.1-GFP. Confocal images of GFP fluorescence were captured on cells from $V$. vinifera cv. Chardonnay calli stably transformed with VvNPR1.1-GFP $(\mathbf{c}$, bar $=5 \mu \mathrm{m})$ and from young leaves of $V v N P R 1.1-G F P$ transformants (T4, d and T7, e). Bar $=10 \mu \mathrm{m}$. Arrows indicate the fluorescence in the nucleus 
constitutively localized to the nucleus and to a lesser extent to the cytoplasm, both in cells of transformed calli (Fig. 4c) and in the leaf cells of transformed grapevine plantlets (Fig. 4d, e).

VvNPR1.1-GFP overexpression in $V$. vinifera results in spontaneous enhanced expression of several $P R$ genes

The expression of several grapevine $P R$ genes was studied by quantitative RT-PCR in independent control and transformed grapevine plantlets that were propagated in vitro (Fig. 5). All five transformants analyzed displayed a stronger constitutive expression of $P R 1, P R 2$ and the acidic chitinase ChitIII compared to WT Chardonnay or plantlets transformed with empty vector (Fig. 5a, b). PR1 and PR2 expression were enhanced 15-300-fold and 8-100-fold, respectively, in the different VvNPR1.1 transformants
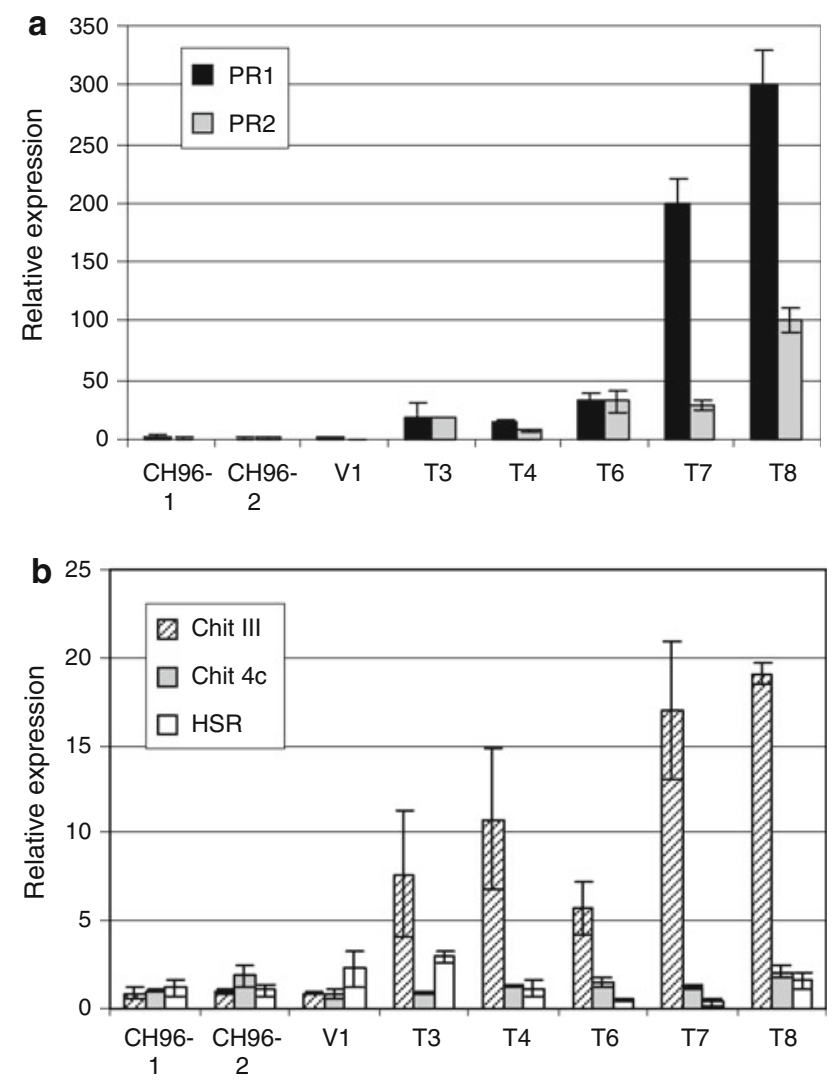

Fig. 5 Constitutive expression of $P R$ genes in leaves of grapevine plantlets overexpressing VvNPR1.1-GFP. Expression levels of $P R 1$, PR2 (a), ChitIII, Chit4c and HSR (b) were studied by quantitative RTPCR in in vitro wild type Chardonnay plantlets (CH96) and in plantlets transformed with the empty vector (V1) or VvNPR1.1-GFP (T3 to T8). Transcript levels of defense genes were normalized to actin transcript levels. The relative expression indicates normalized expression levels in transformed plants compared to normalized expression levels observed in $\mathrm{CH} 96$. Mean values and standard deviations were obtained from 3 technical and 2 biological replicates compared to the controls (Fig. 5a). PRl expression was particularly high in transformants 7 and 8 , which were characterized by a high level of transgene expression (Fig. 4). ChitIII basal expression was increased 5-20-fold by VVNPR1.1 expression. In contrast, the expression of Chit $4 c$, another defense marker, was not enhanced by $V v N P R 1.1$ expression. Similarly, the expression of $V v H S R$, which is associated with hypersensitive cell death (Bézier et al. 2002), was not stimulated in VvNPR1.1 plants (Fig. 5b).

VvNPR1.1-GFP overexpression in V. vinifera is associated with enhanced resistance to powdery mildew

Because grapevine plantlets overexpressing $V v N P R 1.1$ $G F P$ show constitutively high expression of $P R$ genes, especially $P R 1$ and $P R 2$, their resistance to the biotrophic powdery mildew agent Erisyphe necator was tested.

Apical young leaves from soil-grown plantlets were harvested, disinfected, placed in Petri dishes on agar medium and inoculated with E. necator conidia. Symptoms of powdery mildew infection (mycelium development and conidia production) were observed 5, 7 and 11 days after inoculation with a stereomicroscope. Figure 6 shows powdery mildew symptoms 7 days after inoculation. WT Chardonnay $(\mathrm{a}, \mathrm{b})$ and empty vector controls $(\mathrm{c}, \mathrm{d})$ were characterized by high mycelium development and widespread sporulation that was easily observed at the edges of the leaves. In VvNPR1.1-GFP transformed plants, mycelium development was reduced and sporulation was restricted to spots compared to controls (Fig. 6e, f). The number of conidia per $\mathrm{cm}^{2}$ of leaf was further quantified 11 days after inoculation for 3 independent transformants (T4, T6 and T7, Fig. 6g). The number of conidia per leaf surface was clearly reduced in the different VvNPRI.1GFP overexpressing transformants compared to WT Chardonnay and empty vector controls (Fig. 6g).

Taken together, these results show that in grapevine plantlets overexpressing $V v N P R 1.1-G F P$, elevated expression of $P R$ genes is associated with higher resistance to E. necator infection.

\section{Discussion}

We have previously identified in Vitis vinifera two putative homologs of AtNPRl, a key signaling element involved in several important plant disease resistance mechanisms (Le Henanff et al. 2009). Whereas defense-related NPR genes form a multigenic family of 4 members in Arabidopsis, only two NPR genes are found in grapevine. Low levels of polymorphism in the two $V v N P R$ genes show that they experienced purifying selection and suggest that they are 

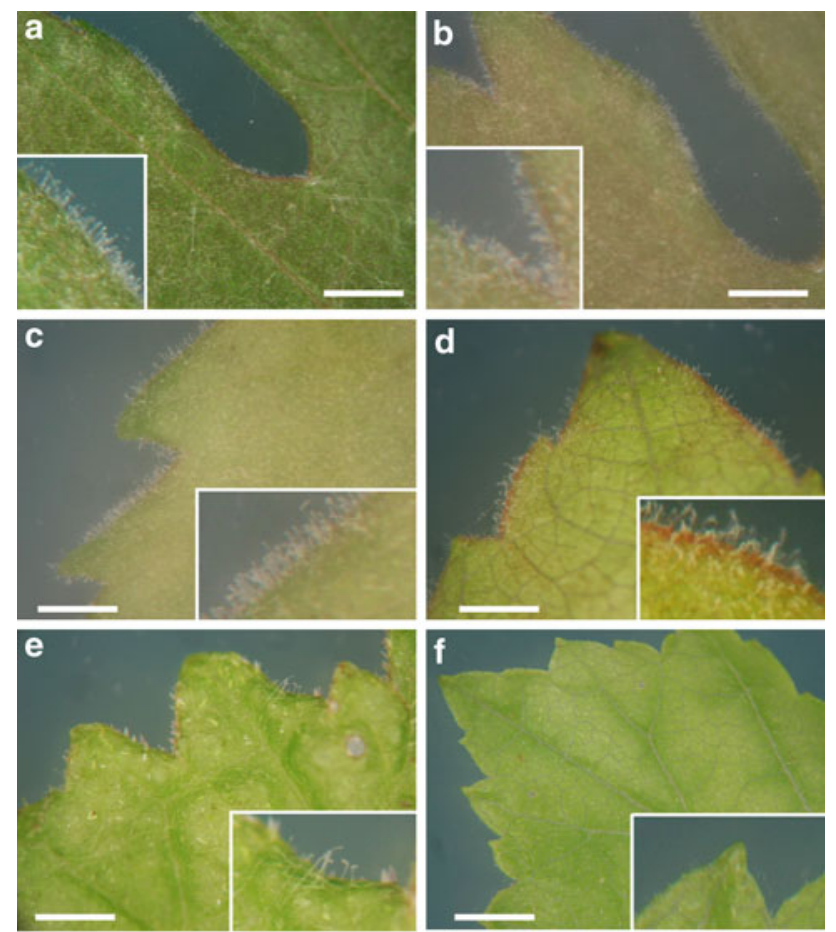

$\mathbf{g}$

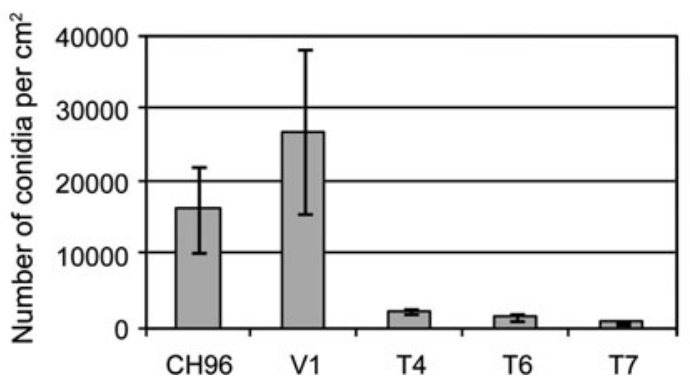

Fig. 6 Enhanced resistance to powdery mildew in grapevine plants expressing VvNPR1.1-GFP. In vitro-grown WT Chardonnay 96 plantlets $(\mathbf{a}, \mathbf{b})$ and plantlets transformed with the empty vector (c, d) or 35S:VvNPR1.1-GFP (e, f) were transferred to soil and inoculated with $E$. necator conidia 4 weeks later. Mycelium development, conidiophore and conidia production are shown for two representative leaves out of 10 for each genotype. Inserts show a $2.5 \times$ enlargement of a part of the pictures. Photographs were taken 7 days after inoculation. Bar $=2.5 \mathrm{~mm}$. The number of E. necator spores per $\mathrm{cm}^{2}$ of leaf was further quantified with a BeckmanCoulter ${ }^{\circledR}$ cell counter in CH96, empty vector plant (V1) and transformants 4, 6 and 7,11 days after inoculation (g). Mean values and standard deviations were obtained with 10 leaves from 4 independent plants for each genotype. Similar results were obtained in three independent experiments

important elements conserved in the Vitaceae family (Bergeault et al. 2010). Previous work from our group has shown that both genes are constitutively expressed in grapevine. In transient assays in Nicotiana benthamiana, VvNPR1.1-GFP and VvNPR1.2-GFP localize predominantly to the nucleus and trigger constitutive accumulation of acidic PR1 and PR2 proteins, which is consistent with a role as transcriptional coactivators (Le Henanff et al. 2009).
Complementation of the Arabidopsis nprl mutation has been performed previously to characterize NPR1 from several crop plants, including rice (Yuan et al. 2007), canola (Potlakayala et al. 2007), soybean (Sandhu et al. 2009), and cacao (Shi et al. 2010). Recently, complementation of the Arabidopsis edsl mutant with grapevine sequences also helped to characterize the function of Vitis EDS1, another central defense regulator acting upstream of SA in pathogen resistance (Gao et al. 2010).

In our study, several lines of evidence show that VvNPRl.1 is the functional ortholog of AtNPRl and is likely to play an important role in both basal and SAinduced resistance in $V$. vinifera. VvNPRI.1 was able to complement all of the deficient phenotypes that have been described for the Arabidopsis nprl mutant. Strikingly, $P R I$ and $P R 2$ expression levels in $n p r 1-2-V v N P R 1.1$ lines were even higher than in WT Col0 after $P$. syringae infection. It is possible that $V v N P R 1.1$ expression driven by the $35 \mathrm{~S}$ promoter in the nprl-2 mutant is stronger than the expression controlled by the native promoter, leading to enhanced signaling and $P R$ gene expression. In contrast, $V v N P R 1.2$ expression did not restore a WT phenotype in the nprl-2 mutant, although sequencing of the full-length $V v N P R 1.2$ RT-PCR products showed that the transcripts are correctly processed in Arabidopsis (data not shown). These results are in accordance with phylogenetic analysis showing that VvNPR1.1 groups close to AtNPR1, whereas VvNPR1.2 belongs to a distinct group comprising the putative negative regulators of defense responses AtNPR3 and AtNPR4 (Bergeault et al. 2010; Le Henanff et al. 2009). Complementation of the Arabidopsis npr $3 / n p r 4$ mutant with $V v N P R 1.2$ as well as $V v N P R 1.2$ overexpression and testing for pathogen resistance in grapevine may help to elucidate the function of this NPR1 homolog in the future.

The enhanced susceptibility of the nprl mutants to virulent pathogens is related to their inability to express specific defense genes, such as $P R 1$ and $P R 2$ (Cao et al. 1994). When $V v N P R 1.1$ was overexpressed in the $n p r l-2$ background, the expression of both defense genes was restored following treatment with SA (Fig. 1c). However, the impact of the nprl-2 mutation on defense gene expression was different upon inoculation with Psm ES4326. In this case, the nprl-2 mutation caused greatly reduced expression of $P R l$ but had no significant effect on $P R 2$ expression (Fig. 3). The expression of $P R 2$ following Psm inoculation was even higher in the nprl-2 mutant transformed with the empty vector than in WT Col0. The nprl-1 mutants were also originally described to be unable to mount a SAR response after pathogen infection (Cao et al. 1994). In our experiments, there was an approximately 10-fold reduction in Psm growth after $72 \mathrm{~h}$ in plants pretreated with SA compared to the non-pretreated plants 
for both the WT and the nprl-2 genotypes (Fig. 2). This finding implies the induction of an SA-dependent, NPR1independent resistance phenomenon that is evidenced in the nprl-2 mutant. These results are in accordance with earlier work describing the isolation of the nprl-2 mutant, where impaired resistance to Psm was associated with reduced expression of $P R 1$ but not of $P R 2$ or $P R 5$, whose expression could be regulated by a NPR1-independent pathway (Glazebrook et al. 1996). In another study, it has been demonstrated that nprl-2 plants are not fully impaired in the induction of SAR, PRI or PR5 expression in response to $P$. syringae carrying AvrB (Zhang and Shapiro 2002). Two pathways may thus be involved in the induction of SAR and $P R$ gene expression. One of these pathways is NPR1 independent and involves signals generated upon hypersensitive cell death (Zhang and Shapiro 2002). Another explanation for SAR and PR2 induction in the nprl-2 mutant could also be related to different effects of the nprl alleles. It is possible that the nprl-1 mutation affects several SA-dependent and -independent functions of NPR1, whereas nprl-2 only interferes with part of NPR1 signaling. This hypothesis is in accordance with results demonstrating that NPR1 could perform different functions. For example, NPR1 is required for the control of Induced Systemic Resistance mediated by beneficial rhizobacteria, a phenomenon that is SA-independent (Pieterse et al. 1998).

To get further insights into VvNPR1.1 function in a homologous system, the gene was overexpressed in fusion with GFP under the control of the $35 \mathrm{~S}$ promoter in grapevine. A loss of apical dominance was observed in all independent transformants that we obtained and is likely related to $V v N P R 1.1$ overexpression. This phenotype is not due to regeneration through somatic embryogenesis because we have previously shown that somaclones from anthers of $V$. vinifera cv. Chardonnay did not show phenotypic differences compared to the parental clone (Bertsch et al. 2005). Moreover, grapevine plantlets transformed with the empty vector did not show a loss of apical dominance (Fig. 4b). The constitutive overexpression of VvNPR1.1-GFP in grapevine led to predominant nuclear localization of the fusion protein and constitutive activation of several $P R$ genes. In a previous study, we have observed a similar behavior of VvNPR1.1 and its protein targets in heterologous transient expression experiments in Nicotiana benthamiana (Le Henanff et al. 2009). Another example of NPRI constitutive overexpression leading to spontaneous activation of defense genes has been described in rice. The ectopic expression of AtNPRI in rice triggers an environmentally controlled lesion mimic/ cell death phenotype, expression of defense genes and accumulation of hydrogen peroxide (Fitzgerald et al. 2004; Quilis et al. 2008). In another study, overexpression of the rice $N P R 1$ ortholog, $N H 1$, led to high levels of resistance to Xanthomonas oryzae pv. oryzae bacteria and spontaneous activation of defense genes (Chern et al. 2005). Interestingly, these results obtained in rice (a monocot) could be compared with our data on grapevine, where constitutive expression of $V v N P R 1.1$ also resulted in the spontaneous activation of $P R$ genes and cell death upon transfer from in vitro culture to soil in growth chambers. These results contrast with data obtained in Arabidopsis, where constitutive overexpression of AtNPRl did not trigger constitutive expression of $P R$ genes (Cao et al. 1998). In the latter case, enhanced $P R$ gene expression was indeed measured only after pathogen attack or SA treatment (Cao et al. 1998). Similar situations have been described following AtNPR1 expression in crop plants, including wheat (Makandar et al. 2006), cotton (Parkhi et al. 2010) and carrot (Wally et al. 2009). In our transgenic grapevines, high levels of $V v N P R 1.1-G F P$ expression in all tissues driven by the $35 \mathrm{~S}$ promoter may trigger constitutive activation of some defense genes. The expression of $V v N P R 1.1$ under the control of its own or an inducible promoter should be considered in future experiments.

In non-induced Arabidopsis plants, NPR1 is present in the cytoplasm as an oligomer maintained through redoxsensitive intermolecular disulfide bonds (Kinkema et al. 2000; Mou et al. 2003). Following treatment with SA or an analog, the NPR1 oligomer is reduced to monomers that are relocalized to the nucleus, resulting in the activation of $P R$ gene expression (Kinkema et al. 2000; Mou et al. 2003). Several conserved cystein residues play an important role in redox-regulated NPR1 localization in Arabidopsis. $\mathrm{Cys}^{82}$ and $\mathrm{Cys}^{216}$ are involved in NPR1 oligomerization because mutations at these residues result in constitutive NPR1 nuclear localization and defense gene expression (Mou et al. 2003). Moreover, a recent study has revealed that S-nitrosylation of NPR1 at cysteine-156 also facilitates its oligomerization (Tada et al. 2008). In our experiments, VvNPR1.1-GFP could be detected in the nuclei of non-induced calli and leaf cells, and this nuclear localization was consistently correlated with the elevated expression of $P R 1$ and $P R 2$, two wellknown markers of the SA pathway. Interestingly, an alignment of the NPR1 amino acid sequences from Arabidopsis and grapevine reveals that $\mathrm{Cys}^{82}$ and $\mathrm{Cys}^{216}$ are conserved, whereas Cys ${ }^{156}$ is absent in VvNPR1.1 (online resource 1). One hypothesis is that the lack of Cys ${ }^{156}$ in VvNPR1.1 could facilitate its oligomerization and constitutive nuclear sequestration. The spontaneous activation of defense genes may thus be related to a different regulation of the NPR1 protein in species such as rice or grapevine.

In VvNPR1.1-GFP transformants, we measured enhanced expression of ChitIII, which has been reported to 
be upregulated by SAR activators (SA, INA, BTH), as well as in adjacent healthy leaves following grapevine pathogen inoculation (Busam et al. 1997). ChitIII may thus represent another marker regulated by the SA/NPR1 signaling pathway in grapevine. In contrast, the gene encoding Chit4c was not affected by VvNPRl.1 overexpression. Because $V v C h i t 4 c$ expression is induced by treatment of grapevine leaves with MeJA or ethephon (Belhadj et al. 2006, 2008), this gene may be regulated by SA/NPR1independent signaling pathways. This latter result thus suggests that overexpression of $V v N P R 1.1$ specifically activates SA-dependent defense genes.

Importantly, grapevine plants that constitutively overexpress $V v N P R 1.1$ exhibited a better resistance to powdery mildew infection. Although we cannot rule out that this phenotype is due to an uncharacterized mechanism triggered by VvNPR1.1 overexpression, the resistance is likely related to the constitutive expression of defense markers of the SA pathway rather than to a general stress response. The expression of stilbene synthase, which is involved in phytoalexin biosynthesis, was not enhanced by VvNPR1.1 overexpression (data not shown). Similarly, the expression of $V v H S R$ was not upregulated in VvNPR1.1 plants, suggesting that VvNPR1.1 overexpression does not constitutively trigger hypersensitive cell death. Quantification of powdery mildew sporulation 11 days after inoculation revealed an approximately 10-fold reduction in VvNPRI.1overexpressing transformants (Fig. $6 \mathrm{~g}$ ). This work thus highlights an important role for VvNPR1.1 in the regulation of SA-dependent responses and resistance to biotrophic pathogens in $V$. vinifera. Moreover, this is the first report of genetic engineering of a signaling element leading to defense gene activation and pathogen resistance in grapevine.

Overall, this study has identified VvNPRl.1 as the functional ortholog of AtNPR1 in grapevine. The strong conservation of $V v N P R 1$ sequence in the Vitaceae family, together with the functional conservation of NPR1 across diverse species such as rice, apple, tomato, cotton and grapevine, points to a prominent role of the NPR1/SAdependent signaling pathway in higher plant resistance to pathogens. This work led us to propose renaming the two grapevine $N P R$ genes $V v N P R 1$ for $V v N P R 1.1$ and $V v N P R 2$ for $V v N P R 1.2$. It is likely that grapevine has a resistance pathway similar to the NPR1-mediated pathway in Arabidopsis. However, as has already been described in rice, the high constitutive expression of NPR1 in grapevine results in side effects, such as cell death in particular conditions and modified morphology, that are likely linked to the constitutive expression of defense genes. "Fitness cost" triggered by NPR1 overexpression may thus hinder manipulation of the SAR pathway as a tool to enhance pathogen resistance in grapevine.
Acknowledgments We are grateful to J. Mutterer (IBMP-CNRS, Strasbourg, France) for help with confocal microscopy observations, to J. Glazebrook (University of Minnesota, St Paul, USA) for $n p r 1-2$ mutant seeds and to J. Dewdney and S. Gopalan (Massachusets General Hospital, Boston, USA) for the PsmES4326 strain. Special thanks to R. Wagner, S. Staerck, M. Kerneis and P. Geoffroy (IBMPCNRS, Strasbourg, France) for taking care of Arabidopsis plants. This work was supported by the Université de Haute Alsace and by a doctoral fellowship from the French Ministry of Research to G. Le Henanff.

\section{References}

Bechtold N, Pelletier G (1998) In planta Agrobacterium-mediated transformation of adult Arabidopsis thaliana plants by vacuum infiltration. Methods Mol Biol 82:259-266

Belhadj A, Saigne C, Telef N, Cluzet S, Bouscaut J, Corio-Costet MF, Merillon JM (2006) Methyl jasmonate induces defense responses in grapevine and triggers protection against Erysiphe necator. J Agric Food Chem 54:9119-9125

Belhadj A, Telef N, Cluzet S, Bouscaut J, Corio-Costet MF, Merillon JM (2008) Ethephon elicits protection against Erysiphe necator in grapevine. J Agric Food Chem 56:5781-5787

Bergeault K, Bertsch C, Merdinoglu D, Walter B (2010) Low level of polymorphism in two putative NPR1 homologs in the Vitaceae family. Biol Direct 5:9

Bertsch C, Kieffer F, Maillot P, Farine S, Butterlin G, Merdinoglu D, Walter B (2005) Genetic chimerism of Vitis vinifera cv. Chardonnay 96 is maintained through organogenesis but not somatic embryogenesis. BMC Plant Biol 5:20

Bézier A, Lambert B, Baillieul F (2002) Cloning of a grapevine Botrytis-responsive gene that has homology to the tobacco hypersensitivity-related hsr203J. J Exp Bot 53:2279-2280

Busam G, Kassemeyer HH, Matern U (1997) Differential expression of chitinases in Vitis vinifera L. responding to systemic acquired resistance activators or fungal challenge. Plant Physiol 115:1029-1038

Cao H, Bowling SA, Gordon AS, Dong X (1994) Characterization of an Arabidopsis mutant that is nonresponsive to inducers of systemic acquired resistance. Plant Cell 11:1583-1592

Cao H, Glazebrook J, Clarke JD, Volko S, Dong X (1997) The Arabidopsis NPRl gene that controls systemic acquired resistance encodes a novel protein containing ankyrin repeats. Cell 88:57-63

Cao H, Li X, Dong X (1998) Generation of broad-spectrum disease resistance by overexpression of an essential regulatory gene in systemic acquired resistance. Proc Natl Acad Sci USA 95:6531-6536

Chern MS, Fitzgerald HA, Yadav RC, Canlas PE, Dong X, Ronald PC (2001) Evidence for a disease-resistance pathway in rice similar to the NPR1-mediated signaling pathway in Arabidopsis. Plant J 27:101-113

Chern MS, Fitzgerald HA, Canlas PE, Navarre DA, Ronald PC (2005) Overexpression of a rice NPRI homolog leads to constitutive activation of defense response and hypersensitivity to light. Mol Plant Microbe Interact 18:511-520

Chong J, Le Henanff G, Bertsch C, Walter B (2008) Identification, expression analysis and characterization of defense and signaling genes in Vitis vinifera. Plant Physiol Biochem 46:469-481

Fitzgerald HA, Chern MS, Navarre R, Ronald PC (2004) Overexpression of $(A t) N P R 1$ in rice leads to a BTH- and environmentinduced lesion-mimic/cell death phenotype. Mol Plant Microbe Interact 17:140-151

Fung RW, Gonzalo M, Fekete C, Kovacs LG, He Y, Marsh E, McIntyre LM, Schachtman DP, Qiu W (2008) Powdery mildew 
induces defense-oriented reprogramming of the transcriptome in a susceptible but not in a resistant grapevine. Plant Physiol 146:236-249

Gao F, Shu X, Ali MB, Howard S, Li N, Winterhagen P, Qiu W, Gassmann W (2010) A functional EDS1 ortholog is differentially regulated in powdery mildew resistant and susceptible grapevines and complements an Arabidopsis eds1 mutant. Planta 231:1037-1047

Glazebrook J (2005) Contrasting mechanisms of defense against biotrophic and necrotrophic pathogens. Annu Rev Phytopathol 43:205-227

Glazebrook J, Rogers EE, Ausubel FM (1996) Isolation of Arabidopsis mutants with enhanced disease susceptibility by direct screening. Genetics 143:973-982

Hepworth SR, Zhang Y, McKim S, Li X, Haughn GW (2005) BLADE-ON-PETIOLE-dependent signaling controls leaf and floral patterning in Arabidopsis. Plant Cell 17:1434-1448

Iriti M, Rossoni M, Borgo M, Faoro F (2004) Benzothiadiazole enhances resveratrol and anthocyanin biosynthesis in grapevine, meanwhile improving resistance to Botrytis cinerea. J Agric Food Chem 52:4406-4413

Karimi M, Inze D, Depicker A (2002) GATEWAY vectors for Agrobacterium-mediated plant transformation. Trends Plant Sci 7:193-195

Katagiri F, Thilmony R, He SY (2002) The Arabidopsis thalianaPseudomonas syringae interaction. In: Somerville C, Meyerowitz E (eds) The arabidopsis book. American Society of Plant Biologists, Rockville

Kinkema M, Fan W, Dong X (2000) Nuclear localization of NPR1 is required for activation of $P R$ gene expression. Plant Cell 12:2339-2350

Le Henanff G, Heitz T, Mestre P, Mutterer J, Walter B, Chong J (2009) Characterization of Vitis vinifera NPR1 homologs involved in the regulation of pathogenesis-related gene expression. BMC Plant Biol 9:54

Lin WC, Lu CF, Wu JW, Cheng ML, Lin YM, Yang NS, Black L, Green SK, Wang JF, Cheng CP (2004) Transgenic tomato plants expressing the Arabidopsis NPRI gene display enhanced resistance to a spectrum of fungal and bacterial diseases. Transgenic Res 13:567-581

Liu G, Holub EB, Alonso JM, Ecker JR, Fobert PR (2005) An Arabidopsis NPR1-like gene, NPR4, is required for disease resistance. Plant J 41:304-318

Makandar R, Essig JS, Schapaugh MA, Trick HN, Shah J (2006) Genetically engineered resistance to Fusarium head blight in wheat by expression of Arabidopsis NPR1. Mol Plant Microbe Interact 19:123-129

Malnoy M, Jin Q, Borejsza-Wysocka EE, He SY, Aldwinckle HS (2007) Overexpression of the apple MpNPR1 gene confers increased disease resistance in Malus $x$ domestica. Mol Plant Microbe Interact 20:1568-1580

Mauro MC, Nef C, Fallot J (1986) Stimulation of somatic embryogenesis and plant regeneration from anther culture of Vitis vinifera cv Cabernet-Sauvignon. Plant Cell Rep 5:377-380

Mou Z, Fan W, Dong X (2003) Inducers of plant systemic acquired resistance regulate NPR1 function through redox changes. Cell 113:935-944

Muthmann R (2007) The use of plant protection products in the European Union. In: Nadin P (ed) Eurostat statistical books. European Commission, Luxembourg

Parkhi V, Kumar V, Campbell LM, Bell AA, Shah J, Rathore KS (2010) Resistance against various fungal pathogens and reniform nematode in transgenic cotton plants expressing Arabidopsis NPR1. Transgenic Res 19:959-975

Perrin M, Martin D, Joly D, Demangeat G, This P, Masson JE (2001) Medium-dependent response of grapevine somatic embryogenic cells. Plant Sci 161:107-116
Pfaffl MW (2001) A new mathematical model for relative quantification in real-time RT-PCR. Nucleic Acids Res 29:e45

Pieterse CM, van Wees SC, van Pelt JA, Knoester M, Laan R, Gerrits H, Weisbeek PJ, van Loon LC (1998) A novel signaling pathway controlling induced systemic resistance in Arabidopsis. Plant Cell 10:1571-1580

Pieterse CM, Leon-Reyes A, Van der Ent S, Van Wees SC (2009) Networking by small-molecule hormones in plant immunity. Nat Chem Biol 5:308-316

Polesani M, Bortesi L, Ferrarini A, Zamboni A, Fasoli M, Zadra C, Lovato A, Pezzotti M, Delledonne M, Polverari A (2010) General and species-specific transcriptional responses to downy mildew infection in a susceptible (Vitis vinifera) and a resistant (V. riparia) grapevine species. BMC Genom 11:117

Potlakayala SD, DeLong C, Sharpe A, Fobert PR (2007) Conservation of NON-EXPRESSOR OF PATHOGENESIS-RELATED GENES1 function between Arabidopsis thaliana and Brassica napus. Physiol Mol Plant Pathol 71:174-183

Quilis J, Penas G, Messeguer J, Brugidou C, San Segundo B (2008) The Arabidopsis AtNPR1 inversely modulates defense responses against fungal, bacterial, or viral pathogens while conferring hypersensitivity to abiotic stresses in transgenic rice. Mol Plant Microbe Interact 21:1215-1231

Ryals J, Weymann K, Lawton K, Friedrich L, Ellis D, Steiner HY, Johnson J, Delaney TP, Jesse T, Vos P, Uknes S (1997) The Arabidopsis NIM1 protein shows homology to the mammalian transcription factor inhibitor I kappa B. Plant Cell 9:425-439

Sandhu D, Tasma IM, Frasch R, Bhattacharyya MK (2009) Systemic acquired resistance in soybean is regulated by two proteins, orthologous to Arabidopsis NPR1. BMC Plant Biol 9:105

Shah J, Tsui F, Klessig DF (1997) Characterization of a salicylic acidinsensitive mutant (sai1) of Arabidopsis thaliana, identified in a selective screen utilizing the SA-inducible expression of the tms 2 gene. Mol Plant Microbe Interact 10:69-78

Shi Z, Maximova SN, Liu Y, Verica J, Guiltinan MJ (2010) Functional analysis of the Theobroma cacao NPRl gene in Arabidopsis. BMC Plant Biol 10:248

Tada Y, Spoel SH, Pajerowska-Mukhtar K, Mou Z, Song J, Wang C, Zuo J, Dong X (2008) Plant immunity requires conformational changes of NPR1 via S-nitrosylation and thioredoxins. Science 321:952-956

Tassoni A, Fornale S, Franceschetti M, Musiani F, Michael AJ, Perry B, Bagni N (2005) Jasmonates and Na-orthovanadate promote resveratrol production in Vitis vinifera cv. Barbera cell cultures. New Phytol 166:895-905

Thomma BPHJ, Eggermont K, Penninckx IAMA, Mauch-Mani B, Vogelsang R, Cammue BPA, Broekaert WF (1998) Separate jasmonate-dependent and salicylate-dependent defense-response pathways in Arabidopsis are essential for resistance to distinct microbial pathogens. Proc Natl Acad Sci USA 95:15107-15111

Thomma BP, Penninckx IA, Broekaert WF, Cammue BP (2001) The complexity of disease signaling in Arabidopsis. Curr Opin Immunol 13:63-68

Wally O, Jayaraj J, Punja ZK (2009) Broad-spectrum disease resistance to necrotrophic and biotrophic pathogens in transgenic carrots (Daucus carota L.) expressing an Arabidopsis NPRI gene. Planta 231:131-141

Yuan Y, Zhong S, Li Q, Zhu Z, Lou Y, Wang L, Wang J, Wang M, Li Q, Yang D, He Z (2007) Functional analysis of rice NPRl-like genes reveals that $O s N P R 1 / N H 1$ is the rice orthologue conferring disease resistance with enhanced herbivore susceptibility. Plant Biotechnol J 5:313-324

Zhang C, Shapiro AD (2002) Two pathways act in an additive rather than obligatorily synergistic fashion to induce systemic acquired resistance and $P R$ gene expression. BMC Plant Biol 2:9 